\begin{tabular}{|l|l|l|l|}
\hline Eiszeitalter u. Gegenwart & 35 & $\begin{array}{c}71-78 \\
2 \mathrm{fig} .\end{array}$ & Hannover 1985 \\
\hline
\end{tabular}

\title{
Late Weichselian and Holocene Marine Transgressions in Northern Jutland, Denmark
}

\author{
Kaj Strand Petersen *)
}

\begin{abstract}
Morphodynamics, marine transgression, marine sedimentation, coastal environment, Late Weichselian, Upper Holocene, boreholes, molluscs, C14 dating, grain size distribution. Northern Jutland
\end{abstract}

A b st ract: An outline on the Late Pleistocene and Holocene marine history of Northern Jutland is given, based on work carried out during the last 10 years. New information regarding the history of the Limfjord is presented, based on two investigation wells at the Agger isthmus, showing a transgression of the southwestern part of the Limfjord during the Boreal and the Early Atlantic followed by a continuous marine sedimentation up to within the Iron Age, $2110 \pm 70 \mathrm{BP}$.

[Spät-weichselzeitliche und holozäne marine Transgressionen im nördlichen Jütland, Dänemark]

K u r z f a s s u n : Aufbauend auf Arbeiten der letzten 10 Jahre wird ein Abriß der spät-pleistozänen und holozänen Entwicklungsgeschichte des nördlichen Jütland gegeben. Neue, die Geschichte des Limfjord betreffende Informationen stützen sich auf zwei Untersuchungsbohrungen im Agger Isthmus. Sie zeigen im südwestlichen Teil des Limfjord eine Transgression während des Boreal und des frühen Atlantikum an, der eine ununterbrochene marine Sedimentation bis in die Eisenzeit, $2110 \pm 70$ v. h., folgt.

\section{Introduction}

Three different sequences of raised marine deposits are represented in Northern Jutland. The so-called Skrerumhede sequence is found in wells and cliff exposures partly disturbed by the ice advance during the Late Middle Weichselian. Exposures of this sequence are found in the cliffs at L $\phi$ kken-L $\phi$ nstrup, bordering the west coast of Vendsyssel, and the sequence appears as the $\mathrm{Old}$ e r Y o ld i a Cla y referring to the dominating bivalve, the high-arctic Portlandia arctica, which together with Macoma species characterize the deposits (BAHNSON et al. 1974). The oldest part of the Skarumhede sequence, the Turritella terebra zone, dates back to the Eemian, which indicates that the northern part of Jutland was covered by an arctic sea during the Weichselian. Middle Weichselian deposits from the same arctic sea are found south of this area on the

*) Address of the author: Dr. K. S. Petersen, Geological Survey of Denmark, Thoravej 31, DK - 2400 Copenhagen NV, Denmark. 
island of Zealand at Holmstrup. The sequence is here dislocated by the Late Middle Weichselian ice advance to the Main Stationary Line, but overlying the deposits from the old Baltic ice advance which have been transgressed by the arctic sea (PETERSEN \& Buch 1974). The high content of ice rafted material demonstrated in the Skarumhede II boring within the Turritella erosa zone might well correlate with the calving of the old Baltic ice lobe in the Kattegat. The correlation between the above-mentioned marine deposits was originally done by way of the foraminiferal assemblages, and recently amino acid work by GIFFORD MILIER has confirmed this correlation.

According to thermoluminescence datings by KRONBORG the Late Middle Weichselian ice advance reached Northern Jutland about 20.000 BP. This terminates the long existing arctic sea within this area (PETERSEN 1984a).

\section{Late Middle and Late Weichselian Sea}

The Younger Yoldia Sea has Portlandia arctica in common with the O $1 \mathrm{~d}$ e $\mathrm{r}$ Yoldi a S e a. The oldest C-14 datings of the Younger Yoldia Se a give an age of 14,000 to $15,000 \mathrm{BP}$. In the shallow water deposits of the Younger Yoldia Sea, the so-called $\mathrm{Z}$ i r p h a e a b e d s, the transition to boreal-arctic communities is found, characterized by Zirphaea crispata. The amelioration is furthermore shown by the occurrence of Mytilus edulis, Macoma baltica and Cyprina islandica. It covers the period from 13,000 to $12,000 \mathrm{BP}$ and is correlated with the B $\phi$ lling interstadial.

The highest shoreline (about 60 metres) is reached between 13,000 and 14,000 BP in the northern part of Vendsyssel, according to the evaluation of fauna communities in relation to depths (Petersen 1984b: fig. 1). The youngest marine Late Weichselian deposits found within the raised marine area, just north of Frederikshavn, can be dated to the end of Aller $\phi \mathrm{d}$. These deposits are dominated by the eulittoral form Mytilus edulis. However, investigations of samples from well sites in the North Sea seem to indicate that the Venus community of deeper water was established already during the Late Weichselian.

The lowering of the sea level took place during the Younger Dryas and into the Holocene, forming a period of erosion where tiver systems intersected the landscape in Northern Jutland. The western part of the later Limfjord system presents a good example of this. Deep furrows have been demonstrated from well data in the raised marine areas and in the fjord itself.

\section{The Holocene Sea}

North of the present Limfjord the former connection with the early stage of the Holocene North Sea has been demonstrated within the Vester Hanherred area at the Vust site (PETERSEN 1981). However, information on the fauna from the Agger area, which now forms the western entrance to the Limfjord through the Thybor $\phi$ n channel, was not at hand.

The present entrance to Nissum Bredning, the westernmost part of the Limfjord, was established in 1825, and this marked a sudden change for the fauna of the Limfjord 
in those days, a change from a brackish water and freshwater fjord to a marine environment. The only connection with the sea antedating 1825 was through the eastern part of the Limfjord facing Kattegat as the passage to the north through the Vester Hanherred area had been closed since the Iron age. However, at sites as e. g. Oddesund in the eastern part of Nissum Bredning the thickness of Holocene marine deposits attained about $25 \mathrm{~m}$, and just inside the present Thybor $\phi$ n channel Holocene marine silt was found to rest on Holocene marine sand to a depth of more than $30 \mathrm{~m}$. These pieces of information seem to indicate that furrows have been formed here during the long interval with low base-level of erosion as seen earlier in the Vester Hanherred area. Faunal analyses from the Agger area itself should consequently elucidate the Holocene transgression and history of any connection between the North Sea and this part of the Limfjord.

\section{The investigation wells at Agger}

In 1983 it was consequently decided to sink two boreholes at the southernmost part of the Agger peninsula, one at the lighthouse and the other $2.2 \mathrm{~km}$ north of this (Agger 1 and 2, DGU Nos 44438 and 36483).

The Agger 1 well reached glacial deposits at a depth of $24 \mathrm{~m}$ below sea level, penetrating about 20 metres of silt and clay overlain by $6 \mathrm{~m}$ of sand. The entire sequence, except the topmost part of sand, contains rich faunas of marine molluscs, parts of which are seen on figure 1 . The molluscan species have been grouped according to the occurrence in littoral and sublittoral zones.

The Agger 2 well did not penetrate the Holocene marine deposits at the final depth of $33 \mathrm{~m}$ below sea level. Here it stopped in sand containing littoral molluscan species as Mytilus edulis, Macoma baltica and Littorina littorea, as seen on figure 2. (This figure is arranged in the same manner as figure 1, with the grain size distribution in weight per cent given to the right, followed by the medial grain size in $\mathrm{mm}$ for each sample analysed.)

It is seen that the two wells have a thick layer of clayey silt in common. Sand and gravel dominate the upper 10 metres in Agger 2 showing the formation of the Agger isthmus. The erosional unconformity is clearly shown by the molluscan fauna in sample No. 12419 (figure 2) at a depth of $6 \mathrm{~m}$ below sea level, compared to the sparse fauna in the superjacent sample No. 12418 at a depth of $5.5 \mathrm{~m}$ below sea level. The level of $6 \mathrm{~m}$ b.s.l. has been C-14 dated to $3650 \pm 80 \mathrm{BP}(\mathrm{K}-4187)$ and represents the topmost part of a sequence with many molluscan species down to about $13 \mathrm{~m} \mathrm{b.s.1}$. This is comparable to the situation in Agger 1 (figure 1) down to nearly the same depth. At a lower level, in Agger 1 to a depth of $23 \mathrm{~m} \mathrm{b.s.l}$. and in Agger 2 to a depth of $30 \mathrm{~m}$ b.s.l., clay and silt are found with a fauna dominated by Corbula gibba and Montacuta bidentata. Furthermore, no littoral species are found such as Mytilus edulis, Cardium edule, Macoma baltica and Littorina (see figures 1 and 2). Such a situation was found also in the Vust borehole (Petersen 1981: fig. 4) where the much larger samples at hand allowed C-14 datings at different intervals showing that a sedimentation rate of $6 \mathrm{~m}$ per 1000 years was reached. In Agger 2 the level at $23 \mathrm{~m} \mathrm{~b}$. s. l. is dated to Early Atlantic, $7290 \pm 110 \mathrm{BP}(\mathrm{K}-4291)$, indicating an equally high sedimentation rate, about $5 \mathrm{~m}$ per 
HOLOCENE MARINE FAUNA

AT AGGER I BOREHOLE 44.438.

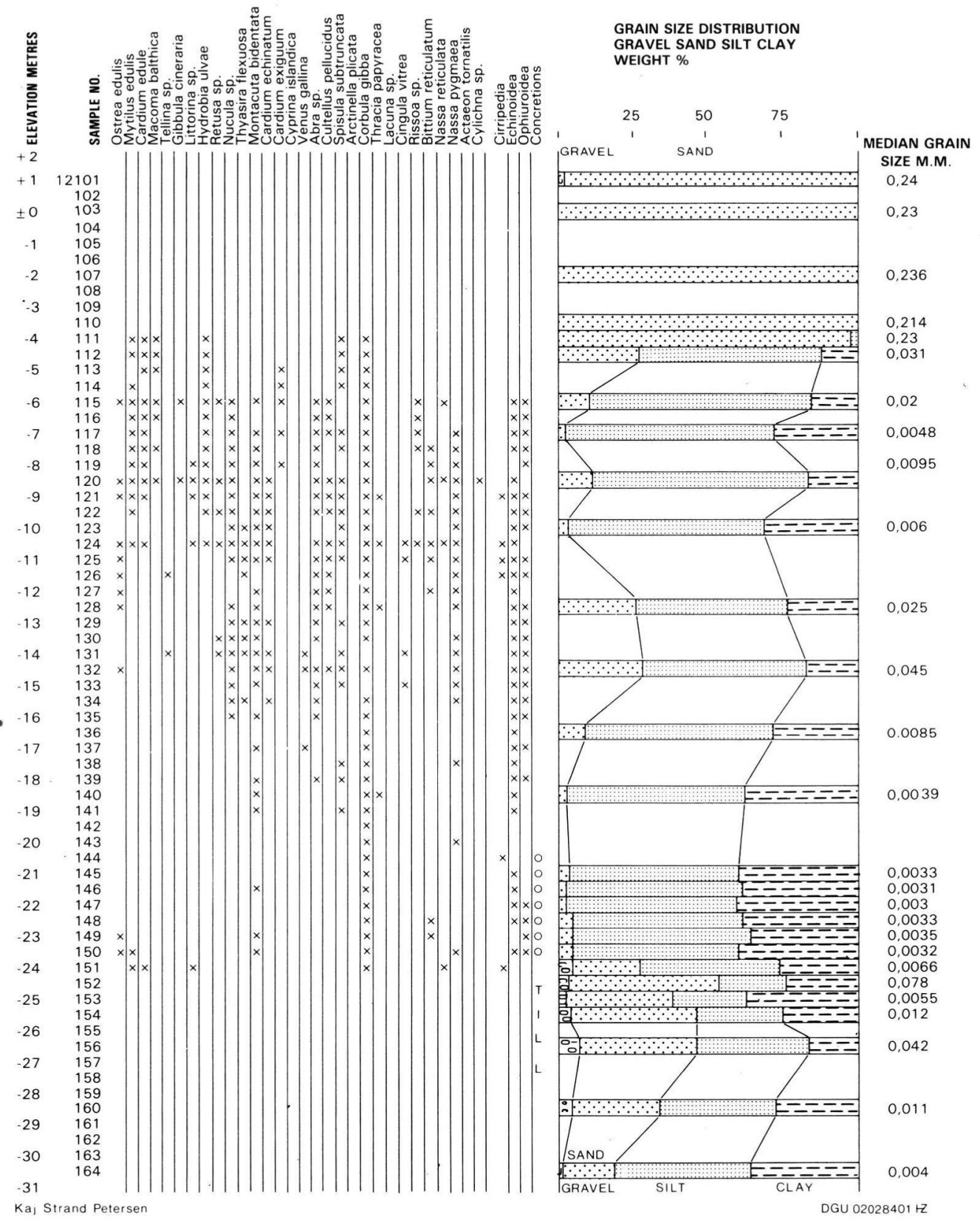

Fig. 1: The Holocene marine fauna, Agger 1 borehole, with the important molluscan species grouped according to their occurrence in the littoral and deeper water zone.

Sample No. 12120 C-14 dated to $2110 \pm 70$ BP (K-4254) and sample No. 12111 C-14 dated to $410 \pm 65 \mathrm{BP}(\mathrm{K}-4186)$. Concretions $=$ shells and Pyrite. 
1000 years. This might explain the low diversity of species, and be in accordance with the studies by LEWY \& SAMTLEBEN (1979) showing that Corbula gibba is particularly adapted to environments of high sedimentation rate.

The bottom layers of sand reached in Agger 2 at a depth of $30-33 \mathrm{~m} \mathrm{~b}$. s. l. have not been dated, but from the molluscan assemblage (figure 2) it is clearly shown that littoral species occur and depict, in comparison with the sequence from Vust, the transgression layers from the Boreal-Early Atlantic.

\section{The molluscan assemblages}

The parallelism between the molluscan assemblages in the two investigation wells appears when comparing the two tables. However, the Agger 2 well must be considered the one covering the largest time interval and having the best indication of sublittoral to littoral species at the base. The occurrence of Mactra stultorum within these layers (sample No. 12471) in Agger 2 sustains the assumption of the shallow water environment and the affinities to the North Sea. The occurrence of Mactra has not been listed, but it appears in Agger 2 within the section at $13 \mathrm{~m} \mathrm{b.s.l}$. (sample No. 12 433) together with Barnea candida.

The interval from $14 \mathrm{~m}$ b.s.l. down to $29 \mathrm{~m}$ b.s.l. is dominated by clayey silt forming a natural ground for Aporrhais pespelicani, one of the characteristic species on muddy bottoms. Furthermore, the drilling activities of Natica are found on the bivalve Corbula gibba.

The uppermost $8 \mathrm{~m}$ of the Agger 2 well are dominated by sand and gravel as seen from the grain size distribution at the right hand side of figure 2 . The fauna depicted from sample No. 12411 (2 m b.s. l.) is allochthonous showing traces of transportation. Furthermore, both littoral and sublittoral species are represented. The listed species could be supplemented by Mya truncata, Barnea candida, Zirphaea crispata, Buccinum undatum and Donax vittatus also found in this sample and all in a transported state. Donax vittatus is a species characteristic of the sandy shore bordering the present day west coast of Northern Jutland. It has also been found in the Agger 1 well (sample No. 12113 ) at a level of $5 \mathrm{~m} \mathrm{b.s.l}$., which constitutes the youngest part of the clayey silt sequence, and is dated between $410 \pm 65$ BP (K-4186) (sample No. 12111) and $2110 \pm 70$ BP (K-4254) (sample No. 12 120). As seen from figure 1 this part of the sequence has a broad representation of the listed species. However, the occurrence of Theodoxus fluviatilis within this part indicates a nearby existing freshwater or brackish water environment. This might be the Limfjord turning into the brackish conditions which prevailed during the last part of the historical time until connection between the Limfjord and the North Sea through the Agger isthmus was reestablished in 1825.

\section{Conclusive remarks}

It has been the author's intention to point out the significance of the marine deposits from the Late Pleistocene and the Holocene as found in Northern Jutland, including the Limfjord region. This comprises the horizontal extension as well as the thickness 
HOLOCENE MARINE FAUNA

AT AGGER II BOREHOLE $\mathbf{3 6 . 4 8 3}$

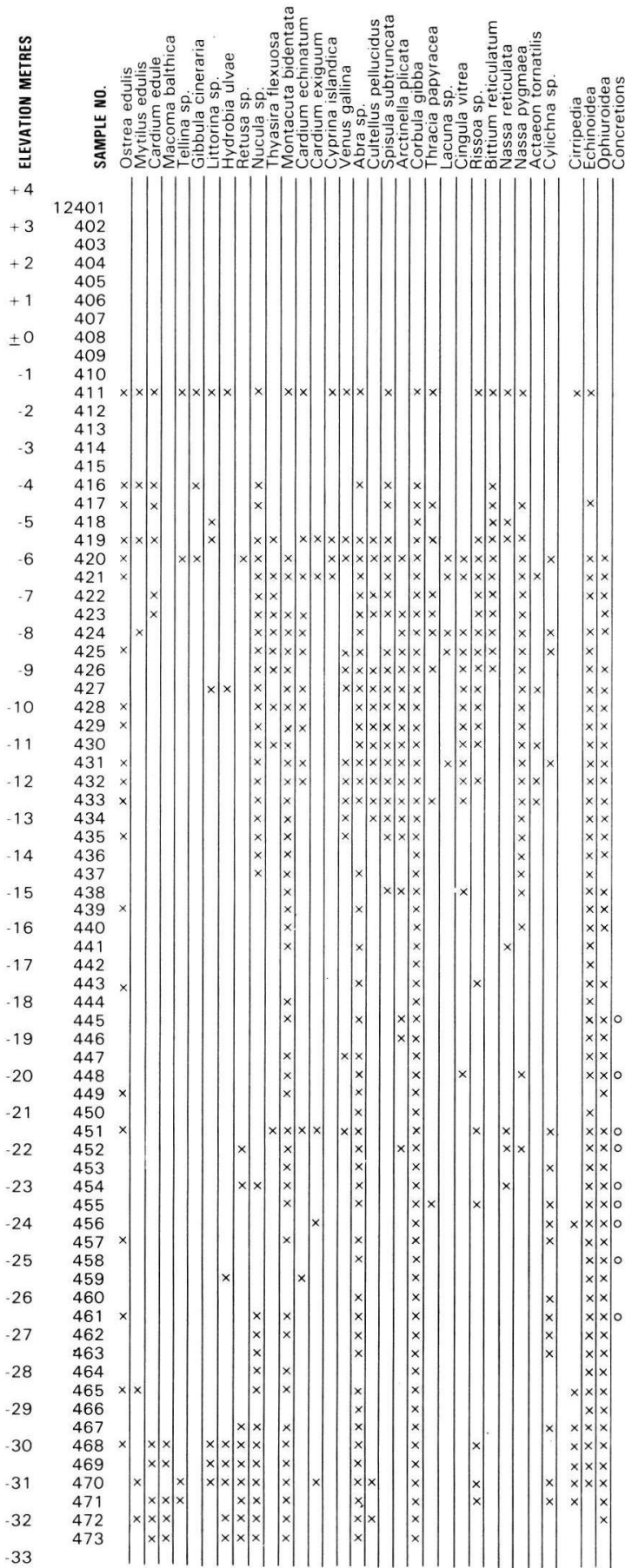

GRAIN SIZE DISTRIBUTION

WEIGHT \%

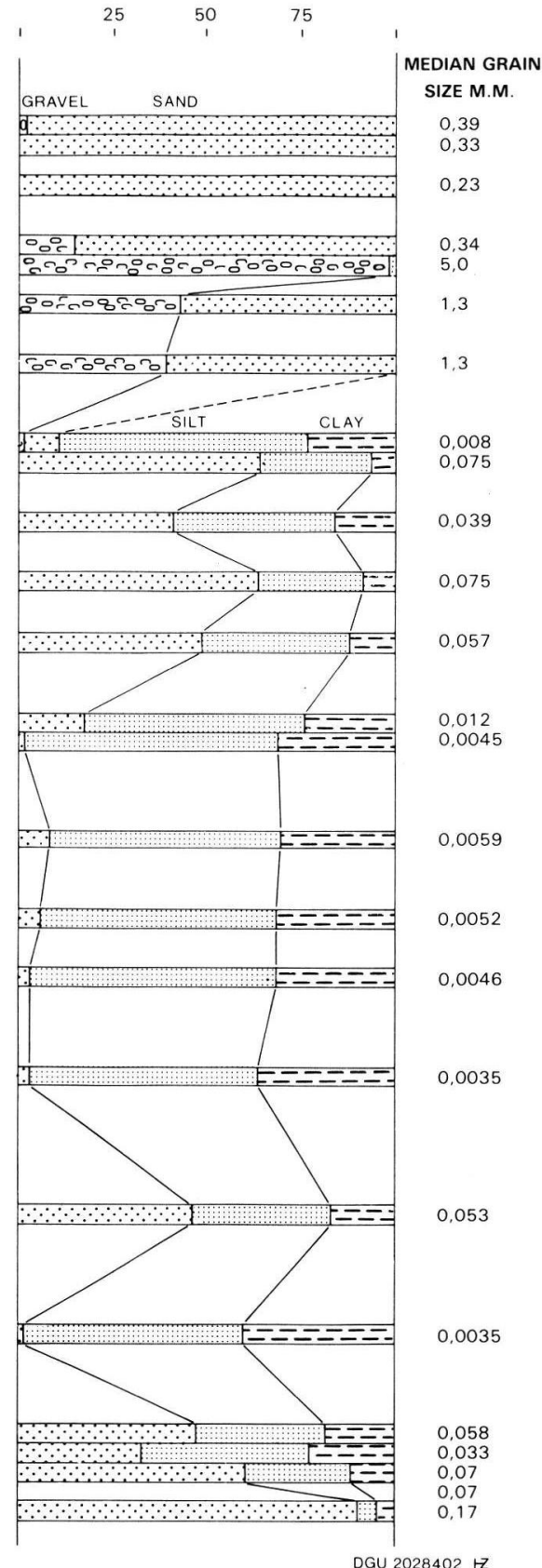


of the strata. The Eemian-Weichselian sequence first known from the Skarumhede wells is underlying large parts of the present day Vendsyssel with a thickness of about $150 \mathrm{~m}$. The uppermost part of this sequence is about $25 \mathrm{~m} \mathrm{b.s.1}$. (BAHNSON et al. 1974: fig. 7). However, as KNUDSEN (1984) writes: "Local tectonic effects cannot be overlooked in this area considering the heights found of certain stratigraphical levels" in various cores. This problem is treated in detail in "Correlation of Saalian, Eemian and Weichselian foraminiferal zones in North Jutland" (KNUDSEN, in press).

The $\mathrm{Y}$ ou nger $\mathrm{Yold}$ i a $\mathrm{S}$ e a deposits cover almost the entire part of Vendsyssel and are now found from the present shoreline up to about $60 \mathrm{~m}$ a.s.l. with the deeper water deposits, the $\mathrm{Y}$ o u $\mathrm{ng}$ e r Yold i a Clay s.s., up to about $30 \mathrm{~m}$ a.s.l. (PETERSEN 1984 b: fig. 1).

The Holocene sea deposits in the northern part of Vendsyssel are found up to $13 \mathrm{~m}$ a.s.l., and bordering the entire part of Northern Jutland. In places these deposits are represented by a marine sequence of more than $35 \mathrm{~m}$, dated back to the Boreal.

The demonstration of sea level changes through this long span of years, where the interaction of eustatic and isostatic movements has functioned, has to be done by evaluating the fauna communities at different depths as demonstrated on the preceding pages.

The conclusion to be drawn from the two investigation wells sunk at the Agger isthmus is that the faunal development here forms a parallel to the situation found in the Vester Hanherred area at Vust and that the Limfjord was also connected with the North Sea in the west over the Agger area. The transgression took place in BorealEarly Atlantic through the erosion furrows formed during the preceding long period (Younger Dryas to Boreal) with low level of erosion base. A continuous marine sedimentation took place, as seen in Agger 1, up until $2110 \pm 70 \mathrm{BP}$. As late as $410 \pm 65 \mathrm{BP}$ ( $4 \mathrm{~m} \mathrm{b.s.1.)}$ marine shells occur, forming a part of the Agger isthmus which was slowly built up of sand and gravel closing the gap to the North Sea, thus forming the basis for the freshwater stage of the Limfjord recorded in its most recent history.

\section{Acknowledgements}

KAREN LUISE KNUDSEN, University of Aarhus, informed me about her most recent investigations (in press). HARALD KROG, Geological Survey of Denmark, critically read the manuscript, BIRGIT NIELSEN corrected the English and typed the manuscript, and Helle ZetTerwall drew the figures. I want to express my gratitude to all these persons.

Fig. 2: The Holocene marine fauna, Agger 2 borehole, with the important molluscan species grouped according to their occurrences in the littoral and deeper water zone.

Sample No. 12454 C-14 dated to $7290 \pm 110$ BP (K-4291) and sample No. 12419 C-14 dated to $3650 \pm 80$ BP (K-4187).

Concretions $=$ shells and Pyrite. 


\section{References}

Bahnson, H., Petersen, K. S., Konradi, P. B. \& Knudsen, K. L. (1974): Stratigraphy of Quaternary deposits in the Skaerumhede II boring: lithology, molluscs and foraminifera. - Danm. geol. Unders., Årbog 1973: 27-62; Copenhagen.

KNUDSEN, K. L. (1984): Foraminiferal stratigraphy in a marine Eemian-Weichselian sequence at Apholm, North Jutland. - Bull. geol. Soc. Denmark, 32, 169-180; Copenhagen.

- (in press): Correlation of Saalian, Eemian and Weichselian foraminiferal zones in North Jutland. - Bull. geol. Soc. Denmark, 33; Copenhagen.

LewY, Z. \& SAmtLeben, C. (1979): Functional morphology and palaeontological significance of the conchiolin layers in corbulid pelecypods. — Lethaia, 12: 341-351; Oslo.

Petersen, K. S. (1981): The Holocene marine transgression and its molluscan fauna in the Skagerrak-Limfjord region, Denmark. - Spec. Publs. int. Ass. Sediment. 5: 497-503; Oxford.

- (1984a): Stratigraphical Position of Weichselian Tills in Denmark. - In: (KÖnIGsson, L.-K. Ed.). Ten Years of Nordic Till Research, Striae, 20: 75-78; Uppsala.

- (1984b): Late Weichselian sea-levels and fauna communities in northern Vendsyssel, Jutland, Denmark. - In: (MÖRnER, N.-A. and KARLÉN, W. Eds.) - Climatic Changes on a Yearly to Millennial Basis: 63-68; Dordrecht (Reidel Publishing Comp.).

- \& Buch, A. (1974): Dislocated tills with Paleogene and Pleistocene marine beds. Tectonics, lithology, macro- and microfossils. - Danm. geol. Unders., Årbog 1973, 63-91; Copenhagen.

Manuscript accepted on 15. 10. 1984 